\title{
HUBUNGAN ANTARA STATUS GIZI DENGAN PRODUKTIVITAS TENAGA KERJA WANITA IKM GIPANG WILAYAH CILEGON
}

\author{
Tri Partuti, Ratna Ekawati \\ Universitas Sultan Ageng Tirtayasa, Banten, Indonesia \\ E-mail: partuti33@gmail.com
}

\begin{abstract}
Work productivity is a concept that shows the relationship between work results and the unit of time needed to produce the product. A worker is said to be productive if he is able to produce more output than other workers for the same unit of time. Work productivity is influenced by several factors, including gender, age, health status / nutritional status, biological disorders of the female workforce, education, years of service and disruption in the work environment. A study of women has been carried out in a number of Gipang Small and Medium Industries (IKM) in the Cilegon area, Banten to determine the relationship between the nutritional status of female workers on the productivity of their work in making gipang (a typical Banten food made from sticky rice mixed with sugar water). The number of respondents as many as 40 people with criteria for female workers aged 20-45 years with healthy conditions, no menstruation, not pregnant, not in the puerperium and menopause, have worked to make gipang at least 2 years and at least educated at the level of junior / equivalent. Data analysis was performed using the statistical regression analysis method. The results of data processing showed that Fcount $<$ Ftable $(0.362<0.55)$ showed that the nutritional value or Body Mass Index (BMI) did not significantly influence the productivity of female workers in GIPang Gipang. The p-value (Significance $F)=0.55$ indicates that height and weight did not significantly influence the nutritional value of female workers. Tcount <ttable also shows that nutritional status does not have a significant effect on work productivity.
\end{abstract}

Keywords: ork productivity, nutritional value, IKM Gipang, regression statistical test

Abstrak. Produktivitas kerja adalah suatu konsep yang menunjukkan adanya kaitan antara hasil kerja dengan satuan waktu yang dibutuhkan untuk menghasilkan produk. Seorang tenaga kerja dikatakan produktif jika ia mampu menghasilkan keluaran (output) yang lebih banyak dari tenaga kerja lain untuk satuan waktu yang sama. Produktivitas kerja dipengaruhi oleh beberapa faktor, diantaranya adalah jenis kelamin, usia, status kesehatan/status gizi, gangguan biologis tenaga kerja wanita, pendidikan, masa kerja dan gangguan di lingkungan kerja. Telah dilakukan penelitian kajian wanita di beberapa Industri Kecil Menengah (IKM) gipang di daerah Cilegon, Banten untuk mengetahui hubungan antara status gizi pekerja wanita terhadap produktivitas kerjanya dalam membuat gipang (makanan khas daerah Banten yang terbuat dari ketan dicampur dengan air gula). Jumlah responden sebanyak 40 orang dengan kriteria tenaga kerja wanita usia 20-45 tahun dengan kondisi sehat, tidak mengalami menstruasi, tidak hamil, tidak dalam masa nifas dan menopouse, telah bekerja membuat gipang minimal 2 tahun dan minimal berpendidikan setingkat SLTP/sederajat. Analisa data dilakukan dengan metode analisis statistik regresi. Hasil pengolahan data didapatkan $\mathrm{F}_{\text {hitung }}<\mathrm{F}_{\text {tabel }}(0,362<$ 0,55) menunjukkan bahwa nilai gizi atau Indeks Masa Tubuh (IMT) tidak berpengaruh secara signifikan terhadap produktivitas pekerja wanita pada IKM gipang. Nilai $p$-value (Significance F) $=0,55$ menunjukkan bahwa tinggi badan dan berat badan tidak berpengaruh secara signifikan terhadap nilai gizi pekerja wanita. Nilai $t_{\text {hitung }}<t_{\text {rabel }}$ juga menunjukkan bahwa status gizi tidak memiliki pengaruh yang signifikan terhadap produktivitas kerja.

Kata Kunci: produktivitas kerja, nilai gizi, IKM gipang, uji statistik regresi

Permalink/DOI: https://doi.org/10.15408/harkat.v15i2.13470 


\section{Pendahuluan}

Pengukuran produktivitas kerja pada dasarnya menyangkut pengukuran terhadap produk yang dihasilkan (out put) dan (input) pengorbanan yang dikeluarkan untuk menghasilkan output tersebut. Kriteria produktivitas kerja antara lain adalah kualitas, kuantitas dan waktu yang dipakai. Untuk memudahkan pengukuran produktivitas kerja, pekerjaan dapat dibagi menjadi dua jenis, pertama, pekerjaan produksi yang hasilnya dapat langsung dihitung dan mutunya dapat dinilai melalui pengujian hasil (quality control) sehingga standar yang obyektif dapat dibuat secara kuantitatif. Kedua, pekerjaan yang non produktif yang hasilnya hanya diperoleh melalui pertimbangan-pertimbangan subyektif misalnya melalui penilaian atasan, teman dan diri sendiri ${ }^{[1]}$.

Produktivitas kerja adalah suatu konsep yang menunjukkan adanya kaitan antara hasil kerja dengan satuan waktu yang dibutuhkan untuk menghasilkan produk. Seorang tenaga kerja dikatakan produktif jika ia mampu menghasilkan keluaran (output) yang lebih banyak dari tenaga kerja lain untuk satuan waktu yang sama. Jadi bila seorang karyawan mampu menghasilkan produk sesuai dengan standar yang telah ditentukan dalam satuan waktu yang lebih singkat, maka karyawan tersebut menunjukkan tingkat produktivitas yang lebih baik atau lebih tinggi ${ }^{[2]}$. Faktor yang mempengaruhi produktivitas kerja diantaranya adalah jenis kelamin $^{[3]}$, usia, status kesehatan/status gizi, gangguan biologis tenaga kerja wanita, pendidikan ${ }^{[4]}$, masa kerja ${ }^{[5]}$ dan gangguan di lingkungan kerja ${ }^{[6]}$.

Status gizi merupakan keadaan kesehatan tubuh seseorang atau sekelompok orang merupakan akibat dari konsumsi, penyerapan (absorption) dan utilisasi (utilization) zat gizi makanan $^{[7]}$. Kekurangan atau kelebihan zat gizi dalam tubuh akan mempengaruhi status gizi yang pada akhirnya menyebabkan masalah gizi. Salah satu cara yang paling sederhana untuk mendiagnosis kekurangan/defisiensi energi kronis adalah dengan menggunakan Indeks Massa Tubuh (IMT). Penggunaan IMT hanya berlaku untuk orang dewasa berumur diatas 18 tahun. IMT tidak dapat diterapkan pada bayi, anak, remaja, ibu hamil dan olahragawan. Disamping itu, IMT tidak bisa diterapkan pada keadaan khusus (penyakit) lainnya seperti adanya edema, asites, dan hepatomegali ${ }^{[8]}$. Rumus perhitungan IMT dapat dihitung menggunakan persamaan 1 . Kategori ambang batas IMT untuk Indonesia dapat dilihat pada Tabel 1.

$$
I M T=\frac{B B(K g)}{\mathrm{TB}^{2}\left(\mathrm{~m}^{2}\right)} \ldots \ldots \ldots \ldots \ldots
$$

Keterangan:

IMT = Indeks Massa Tubuh

$\mathrm{BB}=$ Berat Badan $(\mathrm{kg})$

$\mathrm{TB}=$ Tinggi Badan $(\mathrm{m})$

Tabel 1. Kategori ambang batas IMT $(\mathrm{kg} / \mathrm{m} 2)$ untuk Indonesia

\begin{tabular}{clr}
\hline $\begin{array}{c}\text { Kondisi } \\
\text { Tubuh }\end{array}$ & \multicolumn{1}{c}{ Kategori } & \multicolumn{1}{c}{ IMT } \\
\hline Kurus & $\begin{array}{l}\text { Kekurangan BB } \\
\text { tingkat ringan } \\
\text { Kekurangan BB } \\
\text { tingkat berat }\end{array}$ & $<17,0$ \\
& & $>17,0-18,5$ \\
\hline \multirow{2}{*}{ Normal } & & 25,0 \\
\hline \multirow{2}{*}{ Gemuk } & $\begin{array}{l}\text { Kelebihan BB tingkat } \\
\text { ringan }\end{array}$ & $>25,0-$ \\
& $\begin{array}{l}\text { Kelebihan BB tingkat } \\
\text { berat }\end{array}$ & 27,0 \\
& & $>27,0$ \\
\hline
\end{tabular}

Industri Kecil Menengah (IKM) gipang yang berada disekitar daerah Cilegon, Banten banyak mempekerjakan wanita untuk proses produksinya, dimana tenaga kerja wanita pada umumnya lebih banyak membutuhkan keterampilan tangan dan kurang memerlukan tenaga jika dibandingkan pria. Berbagai 
gangguan yang dapat timbul pada produktivitas tenaga kerja wanita antara lain: siklus haid yang tidak teratur, kehamilan, masa nifas, dan menopause. Beberapa gangguan tersebut secara alamiah juga dapat mempengaruhi kebutuhan gizi tenaga kerja wanita. Berdasarkan hal ini, maka dilakukan penelitian untuk mengetahui hubungan status gizi pekerja wanita di IKM gipang terhadap produktivitasnya dalam membuat gipang.

\section{Metode}

Data penelitian diperoleh dengan meyebarkan kuesioner kepada 40 orang responden khusus tenaga kerja wanita di IKM gipang daerah Cilegon dan sekitarnya, dengan rentang usia 20-45 tahun, kondisi sehat, tidak mengalami menstruasi, tidak hamil, tidak dalam masa nifas dan menopouse, telah bekerja membuat gipang minimal 2 tahun dan minimal berpendidikan setingkat SLTP/sederajat.

Analisa data dilakukan dengan menggunakan uji statistik regresi untuk mengetahui nilai $\mathrm{F}$, p-value dan t sehingga dapat menentukan ada tidaknya hubungan yang signifikan antara nilai gizi tenaga kerja wanita IKM gipang dengan produktivitas kerjanya.

\section{Hasil dan Pembahasan}

\section{Pengelompokan Data Responden}

Berdasarkan data yang telah diolah dari sejumlah responden tenaga kerja wanita di IKM gipang wilayah Cilegon dan sekitarnya, diketahui bahwa tenaga kerja wanita yang tamat Sekolah Dasar berjumlah 27\%, tingkat SLTP/sederajat 40\% dan SLTA/sederajat adalah 33\% (Gambar $1)$.

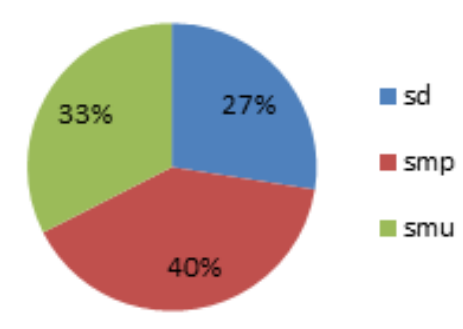

Gambar 1. Prosentase berdasarkan Pendidikan

Prosentase usia tenaga kerja wanita IKM Gipang wilayah Cilegon dan sekitar adalah usia 21-30 tahun berjumlah $12 \%$, usia 31-40 tahun berjumlah $32 \%$, usia $41-50$ tahun $43 \%$ dan usia 51-60 tahun 13\% (Gambar 2).

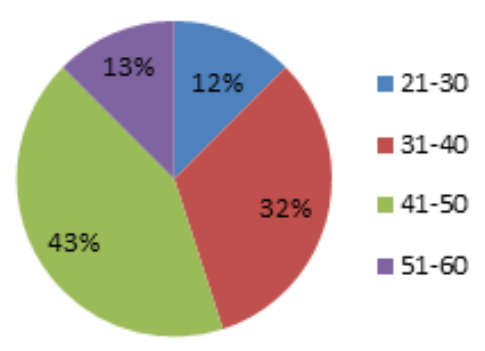

\section{Gambar 2. Prosentase berdasarkan Usia}

Berdasarkan kategori ambang batas IMT pada Tabel 1 dapat diketahui kategori status gizi responden tenaga kerja wanita IKM gipang, yaitu sebanyak $15 \%$ yang berada pada kategori kurus, kategori normal sebanyak $47 \%$ dan kategori gemuk sebanyak 38\% (Gambar 3).

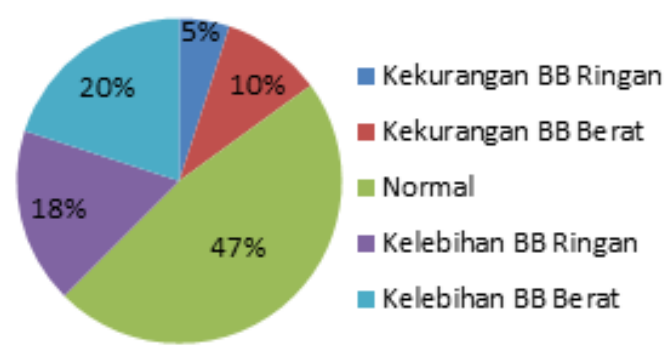

\section{Gambar 3. Prosentasi berdasarkan Status Gizi/IMT}

Seseorang yang kurus dengan kekurangan berat badan tingkat berat maupun ringan maka biasanya orang tersebut akan kurang mampu bekerja, sedangkan orang gemuk atau kelebihan berat badan maka orang tersebut biasanya kurang gesit atau lamban dalam bekerja. 
Sedangkan orang yang memiliki berat badan normal atau proporsional akan lebih lincah atau gesit dalam bekerja.

IKM gipang yang berada di wilayah Cilegon dan sekitar nya memiliki model produksinya adalah Make to Stock dan juga Make to order. IKM yang memiliki model Make to stock biasanya adalah IKM yang telah memiliki outlet-outlet atau toko-toko untuk dapat men-display produk gipang. Sedangkan IKM gipang dengan model make to order adalah IKM rumahan yang hanya memproduksi berdasarkan pesanan dari para pelanggan. Berdasarkan hasil prosentase produktivitas responden dapat disimpulkan bahawa 60\% responden memiliki produktivitas atau menghasilkan produk gipang kurang dari 10.000, sedangkan $32 \%$ responden dapat menghasilkan produk gipang antara 10.000 50.000 dan $8 \%$ memiliki produktivitas atau menghasilkan produk gipang $>100.000$ dalam waktu sekali produksi (Gambar 4). Karena hampir rata-rata IKM gipang menerima banyak pesanan ketika ada acara-acara khusus, seperti hari lebaran dan sebagainya.

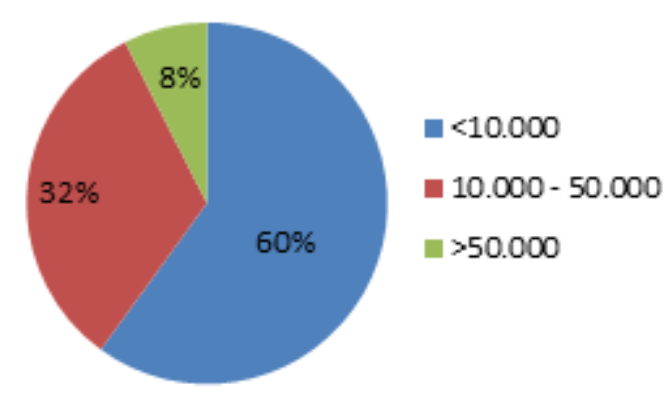

\section{Gambar 4. Prosentase Produktivitas}

\section{Analisa Statistik Regresi}

Multiple R ( $\mathrm{R}$ majemuk) adalah suatu ukuran untuk mengukur tingkat (keeratan) hubungan linear antara variabel terikat dengan seluruh variabel bebas secara bersama-sama. Pada kasus dua variabel (satu variabel terikat dan satu variabel bebas), besaran $r$ (biasa dituliskan dengan huruf kecil untuk dua variabel) dapat bernilai positif maupun negatif (antara $-1-1$ ), Pada kasus ini nilai multiple $\mathrm{R}$ yang diperoleh adalah sebesar 0,09 yang memiliki arti bahwa antara nilai gizi terhadap produktivitas adalah berhubungan kuat karena mendekati nilai positif seperti terlihat pada Tabel 2.

Tabel 2. Hasil Statistik Regresi

\begin{tabular}{ll}
\hline Multiple R & 0,097265526 \\
R Square & 0,009460583 \\
Adjusted R Square & $-0,016606244$ \\
Standard Error & 23654,04178 \\
Observations & 40 \\
\hline
\end{tabular}

$\mathrm{R}$ Square $\left(\mathrm{R}^{2}\right)$ sering disebut dengan koefisien determinasi, adalah mengukur kebaikan suai (goodness of fit) dari persamaan regresi; yaitu memberikan proporsi atau persentase variasi total dalam variabel terikat yang dijelaskan oleh variabel bebas. Nilai $R^{2}$ terletak antara $0-1$, dan kecocokan model dikatakan lebih baik kalau $\mathrm{R}^{2}$ semakin mendekati 1. Kecocokan model antara nilai gizi dan produktivitas dapat dikatakan baik karena memiliki nilai 0,009 seperti terlihat pada Tabel 2.

\section{Pada tabel ANOVA (Tabel 3)} diungkapkan bahwa keragaman data aktual variabel terikat (nilai gizi /IMT) bersumber dari model regresi dan dari residual. Dalam pengertian sederhana untuk kasus ini adalah variasi (turun-naiknya atau besar kecilnya nilai gizi disebabkan oleh variasi dari tinggi badan dan berat badan responden atau pekerja wanita IKM gipang (model regresi) serta dari faktor-faktor lainnya yang mempengaruhi nilai gizi yang tidak dimasukkan dalam model regresi (residual). Selanjutnya kolom MS (Mean of Square) atau rata-rata jumlah kuadrat adalah hasil bagi antara kolom $S S$ dengan kolom $\mathrm{d} f$. Dari perhitungan $M S$ ini, selanjutnya dengan membagi antara MS Regression dengan $M S$ Residual didapatkan nilai F. Nilai $F$ ini yang dikenal dengan $\mathrm{F}_{\text {hitung }}$ dalam pengujian hipotesa dan dibandingkan dengan nilai $\mathrm{F}_{\text {tabel }}$ Hasil pengolahan data didapatkan $\mathrm{F}_{\text {hitung }}<\mathrm{F}_{\text {tabel }}$ dengan 
nilai $F_{\text {hitung }}$ adalah 0,362 dan $F_{\text {tabel }} 0,55$ sehingga dapat dinyatakan bahwa secara simultan (bersama-sama) nilai gizi atau IMT tidak memiliki atau tidak berpengaruh secara signifikan terhadap produktivitas pekerja wanita pada IKM gipang.

Tabel 3. Analisa Tabel ANOVA

\begin{tabular}{llllll}
\hline & $\mathrm{d}$ & $S S$ & $M S$ & $F$ & $\begin{array}{l}\text { Signifi } \\
\text { cance } \\
\end{array}$ \\
& $f$ & & & & $F$ \\
\hline Regre & 1 & 203067 & 20306 & 0,3629 & 0,5504 \\
ssion & & 505,8 & 7505,8 & 35722 & 58671 \\
Resid & 3 & 212615 & 55951 & & \\
ual & 8 & 20320 & 3692,6 & & \\
Total & 3 & 214645 & & & \\
& 9 & 87826 & & & \\
& & & & & \\
\hline
\end{tabular}

Selain itu, kita juga bisa membandingkan antara taraf nyata dengan $p$-value (dalam istilah Excel adalah Significance F). Jika taraf nyata < dari p-value maka kesimpulannya adalah sama seperti di atas. Misalnya ingin menetapkan taraf nyata 5\%. Karena p-value (Significance F) = 0,55, maka dapat dikatakan bahwa tinggi badan dan berat badan secara bersama-bersama tidak berpengaruh secara signifikan terhadap nilai gizi pekerja wanita pada IKM gipang wilayah Cilegon dan sekitarnya (Tabel 3).

\section{Hasil Uji Parsial}

Dalam pengujian hipotesis regresi, tahap berikutnya setelah pengujian secara simultan (uji F) adalah pengujian koefisien regresi secara parsial. Pengertian pengujian secara parsial ini adalah untuk menjawab pertanyaan "dengan asumsi faktor-faktor lain tetap/tidak berubah, apakah status gizi atau IMT berpengaruh terhadap Produktivitas ?". Dalam uji parsial ini menggunakan uji $t$, yaitu membandingkan antara $t_{\text {hitung }}\left(t_{\text {stal }}\right)$ dengan $t_{\text {tabel }}$. Jika $t_{\text {hitung }}>t_{\text {tabel }}$ pada taraf nyata tertentu, maka dapat disimpulkan variabel tersebut berpengaruh secara signifikan dan jika $t_{\text {hitung }}<\mathrm{t}_{\text {tabel }}$ maka dapat disimpulkan bahwa variabel tersebut tidak memiliki pengaruh secara signifikan. $t_{\text {hitung }}$ merupakan hasil bagi antara Coefficiens dengan Standard Error seperti terlihat pada Tabel 4. Perhitungan ini dalam kasus yang umum, digunakan Hipotesis nol $\left(\mathrm{H}_{\mathrm{o}}\right)$ $=0$. Untuk kasus dimana $\mathrm{H}_{\mathrm{o}}$ lebih besar/kecil dari 0, maka perlu dilakukan perhitungan manual. Selain membandingkan dengan nilai $\mathrm{t}_{\text {tabel}}$, kesimpulan secara signifikan juga bisa dilakukan dengan membandingkan taraf nyata dengan $p$-value. Misalkan menggunakan taraf nyata $5 \%$, maka variabel dengan $p$-value sama atau lebih kecil dari 5\%, dapat dinyatakan sebagai variabel yang secara parsial berpengaruh signifikan. Hasil yang didapat menggunakan add ins Excel menyatakan bahwa $\mathrm{t}_{\text {hitung }}<\mathrm{t}_{\text {tabel }}$ maka status gizi atau IMT tidak memiliki pengaruh yang signifikan terhadap produktivitas. Hal ini terjadi karena dalam IKM gipang benar tidak dipengaruhi oleh status gizi karena pekerjaan nya yang tidak membutuhkan gizi yang tinggi. Atau dengan proporsi tubuh kurus normal dan gemuk para pekerja dapat memproduksi gipang dengan baik.

Tabel 4. Analisa Uji Parsial

\begin{tabular}{lll}
\hline & Intercept & X Variable 1 \\
\hline Coefficient & $1.394,9149$ & 500,9461 \\
Standard & $20.457,0907$ & 831,5266 \\
Error & & \\
$\boldsymbol{t}_{\text {stat }}$ & 0,0682 & 0,6024 \\
p-value & 0,9460 & 0,5505 \\
Lower 95\% & $(40.018,2999)$ & $(1.182,3915)$ \\
Upper 95\% & $42.808,1296$ & $2.184,2837$ \\
Lower 95,0\% & $(40.018,2999)$ & $(1.182,3915)$ \\
Upper 95,0\% & $42.808,1296$ & $2.184,2837$ \\
\hline
\end{tabular}

Tidak berpengaruh secara signifikan terhadap nilai gizi pekerja wanita pada IKM gipang wilayah Cilegon dan sekitarnya karena pada IKM gipang benar tidak dipengaruhi oleh status gizi disebabkan pekerjaannya yang tidak membutuhkan gizi yang tinggi. Dengan proporsi tubuh kurus, normal dan gemuk para pekerja dapat memproduksi gipang dengan baik. 


\section{Penutup}

Dengan demikian hasil dari pengolahan data didapatkan $\mathrm{F}_{\text {hitung }}<\mathrm{F}_{\text {tabel }}(0,362<0,55)$ menunjukkan bahwa nilai gizi atau Indeks Masa Tubuh (IMT) tidak berpengaruh secara signifikan terhadap produktivitas pekerja wanita pada IKM gipang. Nilai p-value (Significance F) $=0,55$ menunjukkan bahwa tinggi badan dan berat badan tidak berpengaruh secara signifikan terhadap nilai gizi pekerja wanita. Nilai $t_{\text {hitung }}$ $<\mathrm{t}_{\text {tabel }}$ juga menunjukkan bahwa status gizi tidak memiliki pengaruh yang signifikan terhadap produktivitas kerja.

\section{Daftar Pustaka}

Nurmawati, R. 1996. Status Gizi dan Kepuasan Kerja dalam Hubungannya dengan Produktivitas Kerja Pekerja Wanita. Tesis. Yogyakarta : Universitas Gadjah Mada

Harsiwi, A.M. 2004. Produktivitas Kerja dan Kesempatan Aktualisasi Diri Dosen Wanita. http://researchengines.com/ipenelitian.html.

Soeripto. 1992. Kebijakan Depnaker Dalam Penerapan Ergonomi Di Indonesia. Majalah volume XXV edisi Januari-Maret

A.M. Sugeng Budiono. 2003. Bunga Rampai HIPERKES DAN KK. Semarang : Badan Penerbit UNDIP

Tulus MA, 1992. Manajemen Sumber Daya Manusia. Jakarta : Gramedia Pustaka

Mariyati Sukarni. 1989. Kesehatan Keluarga dan Lingkungan. Bogor : IPB

Riyadi H. 1996. Gizi dan Kesehatan dalam Pembangunan Pertanian. Bogor: IPB Press

Supariasa IDN, Bakri B, Fajar I. 2002. Penilaian Status Gizi. Jakarta: EGC. 